\title{
APPROACHES OF MATHEMATICAL AND PEDAGOGICAL SCIENTISTS IN THE TEACHING OF TEXTUAL PROBLEMS IN GENERAL SECONDARY SCHOOLS
}

\author{
Gulhayo Bahodirovna Kuzmanova
}

Teacher, Department Of Primary Education, Chirchik State Pedagogical Institute, Uzbekistan

\section{ABSTRACT}

The article focuses on the educational significance of mathematical and pedagogical scientists of Europe, the CIS and our country, problem-solving methods, techniques, problems in improving the methods of teaching textual problems in secondary schools, the implementation of measures.

KEYWORDS: - Problem, mathematical, method, pedagogical, differential, problem, model, solution, scheme, event, reader, improvement,

\section{INTRODUCTION}

It can be said that a textual matter represents a verbal model of a situation, event, process, and so on. As in any model, not all events and processes are fully reflected in a textual issue, but their quantitative and functional aspects are reflected, and the main difficulty is to identify ways to solve the problem.

In the methodical manual of M.Sh.Mamatov and D.M.Mahmudova "Methods of development of independent creative activity of students by means of problem-solving" the problem problems and their solutions on various subjects from different branches of mathematics are presented and their solutions are described. In particular, a methodology for constructing and solving problems in the field of optimal management, differential games has been developed [ec; 94-95-p.].

In our country, it is important to further improve education, use modern knowledge and pedagogical technologies, apply new modern teaching methods in the teaching process, increase students 'interest in education, keep abreast of world scientists' scientific discoveries. In particular, J.L. In an article by Yin Kwan and W. W. Lan Chan in the April 2021 issue of Contemporary Educational Psychology, No. 65, entitled "The Role of Methods in Solving Textual Problems in Mathematical Schemes," some readers may have difficulty solving textual problems and understanding their content. The role of schematic analysis of issues in solving this problem has been studied in depth. A scheme is a framework for organizing knowledge that serves 
CURRENT RESEARCH JOURNAL OF PEDAGOGICS 2(8): 80-83, August

2021 DOI: https://doi.org/10.37547/pedagogics-crjp-02-08-18

ISSN 2767-3278

(C)2021 Master Journals

\section{Crossref do) 81 Google}

Accepted $26^{\text {th }}$ August, 2021 \& Published 31 th August, 2021

as a basis for expressing the content of an issue.

And Belgian scientists M. Marinova, D. Sasanguie, B. Reynvoet's article in Reseatc in Developmental Disabilities, October 105, 2020, entitled "Ways to Facilitate Mathematical Problem Solving in Mathematics for Schoolchildren with Disabilities," discusses the analysis of students' mathematical abilities and executive functions.

In addition, Finnish scientists E. Kikas, E. Pakarinenning "Learning and Individual Differens. In the October 75, 2019 issue of the journal "Teacher's Practice in Solving Textual Problems and Developing Their Oral Computational Skills," he explored the relationship between students 'mathematical skills formation and teaching practice and process. Their consists in the application of methods of developing verbal arithmetic skills.

R. Winkler, a German scientists, in an article entitled "Intelligent Personal Assistant Technology" in the May 2021 issue of Computer Education, entitled "Intelligent Personal Assistant Technology to Improve Problem Solving Skills for Students," states that smart personal assistants, i.e. computer technology, solve problems that are impossible. In this regard, the further development of students' knowledge and skills in information technology is of great importance. It is useful to fill in the gaps in the use of information technology in solving textual problems.

U.S. scientists S Lynn, K Jennifer, F. Gilbert's article, "The Difference Between Mathematical Problems and Oral Textual Problems," in the January 60, 2020 issue of Contemporary Educational Psychology, evaluates the relationships between the processes of solving oral text problems from general textual problems. A survey was conducted to identify students who were distinguished by their thinking, memory, classroom behavior, speech comprehension, computational speed, and problem-solving skills, and identified students' ability to solve text problems. At the same time, it was found that students with the ability to solve verbal problems are students with faster computational speed and better comprehension of speech.

Another U.S. scientist, K.S. Jitendra, J. Woodward's article, "The Role of Visual Images in Solving Textual Problems," in the 5th issue of Cognitive Foundations for Improving Mathematical Learning, 2019, examines the role of visual images, such as pictures, drawings, and diagrams, in the process of studying and solving textual problems. Studies have shown that the use of such visual images is effective in solving textual problems.

Esemin Kopur-GenKturk, a Canadian scientist, in Tenzin Doleck's May 2021 issue of Teaching and Teacher Education, issue 101, "Linking Teachers to Fractions in Solving Textual Problems," argues that solving teachers 'fractions is important in solving text problems. Solving equations in the form of fractions in solving textual problems requires direct use in its properties to reveal the essence of fractions.

Sarah Malone, a German scholar, wrote in the December 2018 issue of Vievin Scopus's journal Learning and Instruction, "Several Symbolic Images; a combination of formulas, images, and graphs can help solve text problems. " The title of the article discusses the role of textual problems in mathematics education and the specifics of using formulas, images and graphs to solve them.

German scholars Jennifer Drose and Susanne Prediger in their May 1, 2021 issue of the journal Studies in Educational Evaluation, "Overcoming Barriers to Solving Textual Problems for FifthGrade Students." Factors that help readers solve textual problems in a title article. Methods of overcoming barriers to problem solving, the ability of the teacher, their professional development, the advantages of using 
CURRENT RESEARCH JOURNAL OF PEDAGOGICS 2(8): 80-83, August

2021 DOI: https://doi.org/10.37547/pedagogics-crjp-02-08-18

ISSN 2767-3278

(C)2021 Master Journals

Crossref dof 81 Google

Accepted $26^{\text {th }}$ August, 2021 \& Published 31 th August, 2021

information technology in solving problems are given.

A.Alexander, S. from Indonesian scientists. Gunawan, R. Pribadi, V. Budiharto's article in the March 2018 issue of the journal Procedure Computer Science, entitled "Indonesian Intelligent Robotic System for Answering Questions in Problem Solving," presents a robotic analysis of problem-solving questions using an arithmetic method in solving textual problems.

S. R. from U.S. scientists. Povel's July 58 issue of The Journal of Mathematical Behavior, entitled "Difficulties in Analyzing Students' Mathematical Problems in Mathematics," was published.

German scholars S. Piel and C. Stuarts in their June 66 issue of the International Journal of Educational Research, No. 66, entitled "The Origin of Mathematical Problems in Mathematics and the Role of Daily Knowledge in Solving Them," The TIMSS international research program highlights the role of textual issues in improving students' mathematical literacy.

\section{REFERENCES}

1. Gulhayo Bakhodirovna Kuzmanova, Nurseit Alijan Ogli Beketov (2020). Use Of Historical Materials In Teaching Mathematics In Continuous Education. The American Journal of Social Science and Education Innovations, 2 (09), 531-537.

2. Seytov, A. J., Esonturdiyev, M. N., Qarshiboyev, O. S., \& Quzmanova, G. B. (2020). APPLICATION OF LOGARIFMS IN SOME LIFE ISSUES. Academic Research in Educational Sciences, 1 (3), 784-788.

3. Kuzmanova GB (2021) Teaching textual issues in secondary schools. Academic Research in Educational Sciences, 2 (3), 1154-1159.
4. Kuzmanova GB THE IMPORTANCE OF INNOVATIVE ACTIVITY IN THE PROCESS OF TEACHING, p343-345

5. Abdullaeva B.P. Abdullaeva F.T. Organization Of Swimming Lessons In Preschool Institutions The American journal of social science and education innovations. JULY 2020 [TAJSSEI] 322ISSN (e): 2689-100X DOI:

https://doi.org/10.37547/tajssei/Volume02 Issue 07-42

6. Mamadaliyev K.R., Jabborova O.M., Umarova Z.A., Abdullaeva B.P. Creation of a New Generation of Teaching Literature -A Requirement of Modernity // SCOPUS International Journal of Psychosocial Rehabilitation, Vol. 24, Special Issue 1, 2020.

7. Жабборова Онахон Маннаповна, Ташпулатова Дилором Мукимовна, Бошланғичсинфўқитувчиларигақўйилади ганталаблар. Academic research in educational sciences, Issue 3,2021, pp 5755827.

8. Жабборова О.М., Умарова 3.А. Тарбия фанини кластер усулида ўқитишдапедагогикконфликтларнибарта рафэтиш. Academic research in educational sciences, Issue 1, 2021, pp 582587.

9. Abdullaeva B.P. Babaraximova B.P. Pardaev B.P.Using information and communication technologies in teaching process of various primary European Journal of Research and Reflection in Educational Sciences, 8 (10), 67-70. Progressive Academic Publishing, UKwww.idpublications.org 14.10.2020.

10. Abdullaeva B.P. Abdullaev F.T. Organization of Swimming Lessons In Preschool Institutions THE AMERICAN JOURNAL OF SOCIAL SCIENCE AND EDUCATION 
CURRENT RESEARCH JOURNAL OF PEDAGOGICS 2(8): 80-83, August

2021 DOI: https://doi.org/10.37547/pedagogics-crjp-02-08-18

ISSN 2767-3278

(C)2021 Master Journals

Crossref dof 81 Google

Accepted $26^{\text {th }}$ August, 2021 \& Published 31 th August, 2021

\section{INNOVATIONS.}

TAJSSEI]322ISSN

JULY

(e):2689-100X

2020[

https://doi.org/10.37547/tajssei/Volume02

Issue $07-423$.

11. Abdullayeva, B.P., \& Babaraximova, B. P. (2020). MAKTABGACHA TA'LIM MUASSASASIDA FUTBOL DARSLARINI TASHKIL ETISH METODIKASI. Academic Research in Educational Sciences http://ares.uz/jurnallar-sahifasi/ares-vol-1- no-3-2020.

12. Abdullaeva B.P. ACADEMICIA: An International Multidisciplinary Research Journal https://saarj.com ORGANIZATION AND METHODOLOGY OF CONDUCTING FOOTBALL LESSONS IN A PRESCHOOL INSTITUTION 650-655 10.5958/22497137.2021.00098. 